\title{
Supply Chain Efficiency in the Discount Store Industry Post COVID-19: Applying the Supply Chain Efficiency Ratio
}

\author{
Kevin Forehand \\ American Public University System, USA \\ Juan Román \\ Embry-Riddle Aeronautical University, USA \\ Thomas Schaefer \\ American Public University System, USA \\ Email: drtjschaefer@gmail.com (Corresponding Author)
}

\begin{abstract}
Over the course of calendar year 2019, businesses around the globe have experienced supply chain disruption due to the COVID-19 global pandemic. The strategic significance of the supply chain has been thrust into the forefront for businesses, economies, and society at large. It has become recognized by researchers and industry that there is a need for higher efficiency within the supply chain while remaining responsive to consumer needs. However, the fragmented and diverse nature of supply chain management, coupled with the complex accountancy and financial outputs of the supply chain, has resulted in limited development of a theoretical foundation specific to supply chain management. The aim of this investigation was to develop a new model (the Supply Chain Efficiency Ratio) that measures supply chain efficiency using financial ratios and by extending the Efficiency Model. Data for this investigation were obtained from U.S.-based public discount stores in the United States. The results of the multiple regression performed indicated that the Supply Chain Efficiency Ratio holds predictive value of an organization's supply chain efficiency $p<0005$. From the study it was found that the Supply Chain Efficiency Ratio can be used as an indicator of supply chain efficiency in discount stores.
\end{abstract}

Keywords: supply chain management, COVID-19, discount store industry, efficiency

\section{INTRODUCTION}

Supply chain efficiency in retailing, according to Walters (2006), has become a dominant corporate paradigm, driving business models and in the short-term delivering improved profitability. The academic literature offers multiple accounts of supply chain structure from the organizational perspective. In addition, supply chain effectiveness has figured prominently on the agenda of organizational management. However, prior studies do not analyze the complex accountancy and financial outputs that provide proof of an efficient supply chain. In addition, there is very limited research on the impact of the COVID-19 pandemic on supply chains or the discount store industry.
The literature suggests additional research is needed in the areas of supply chain efficiency and its influence on firm financial performance. For instance, a review of the literature on theoretical model in supply chain management conducted by Liao and Widowati (2021), indicated only a few models with moderator designs have been developed to measure firm financial performance and supply chain efficiencies. This study only examines moderator designs; we will examine any change in the relationship between the independent variable (i.e., supply chain efficiency) and a dependent variable (i.e., financial performance).

Key models noted by the authors include: Wiengarten, Pagell, Ahmed, and Gimenez (2014) who measured the impact of supply chain integration on firm performance in Spanish logistics firms via regression model; Wong, Lai, and Bernroider (2015) who measured the impact of supply chain information integration on firm performance in Hong Kongbased trade companies' firms via a Chi-Square model; Eckstein, Goellner, Blome, and Henke (2015) who measured the impact of supply adaptability on cost/operational performance in German firms via a hierarchical regression model; Yoon, Lee, and Schniederjans (2016) who measured the impact of leadership on supply chain efficiency in South Korean medical service facilities via a structural equation model; and Gligor (2017) who measured the impact of supply chain fit on financial performance in 17 U.S. industries via a hierarchical moderated regression model.

Of note, the impact of COVID-19 on supply chain efficiency and financial performance is not listed since the pandemic had not become a pressing business performance issue, which is a significant research gap. In addition, no models have been developed that examine the discount store industry, another significant gap in the supply chain literature. Other research gaps include the findings of Yalcin, Shi and Rahman (2020), who found sufficient research on firm performance and supply chain but very little research that combines both topics.

Kahn and Wisner (2019) examined the interrelationships among supply chain integration, learning, agility and organizational performance. The author found that supply chain integration and external learning had an 
insignificant impact on firm performance whilst internal learning had an influence on business functions. Muktar and Azhar (2020) argued that the integration of value chains functions is a source of higher competitiveness for the supply chain, which had an impact on superior customer value. However, the authors do not examine if that competitiveness translates into better firm performance and indicate that further research on the impact of supply chain on firm financial performance is needed.

The current literature does not provide a sufficient exploration for the measurement and understanding of true supply chain efficiency, providing limited utility for academics and practitioners in both the consumer defensive sector and the discount stores industry. This investigation will be the first contribution of the impact of supply chain efficiency on firm performance within the discount store industry. A significant motivation of the authors is to begin empirical research on the influence of COVID-19 on supply chain and firm finances.

\section{LITERATURE REVIEW}

Supply chain management (SCM) spans all movement and storage of raw material, work in process inventory, and finished goods from point of origin to point of consumption (Singh \& Raghuvanshi, 2014). Given the limited empirical research on the role of SCM in both the consumer defensive sector and the discount stores industry, published research on the role of SCM in the retail industry is discussed in this literature review based on existing similarities between the two industries. The strategic significance of the supply chain is clearly understood by retailers because it represents a source of competitive advantage (Singh \& Raghuvanshi, 2014). For the retail industry, the need to achieve higher efficiency in distribution and remain responsive to customer needs is of vital importance.

Distribution impacts directly on the competitiveness of a firm as it affects both the supply chain cost and the customer experience (Lau, 2012, p. 639). This concept holds true in the discount stores industry, which is comprised of large scale, big-box stores where competition increases the need for both effectiveness and efficiency. Through this lens, discount stores utilize a sophisticated information technology and point-of-sale network with suppliers to provide the proper amount of goods needed to optimize onhand inventory and to satisfy consumer demand.

In retail, where competition is intense and stakes are high, customer satisfaction is paramount. In summary, a company's financial performance and its position in the supply chain also has a bearing on organizational strategy, such that most evidence of customer focused behavior and decision making is to be found within organizations that are performing well (Singh \& Raghuvanshi, 2014). With that said, organizational performance in 2020 has been a challenge across most sectors and industries due to the COVID-19 global pandemic.

\subsection{COVID-19 Impact on Supply Chains}

Current research suggests supply chains across the globe have experienced disruption due to the COVID-19 global pandemic. This includes the supply chains for areas such as agriculture and food distribution to medical personal protective equipment and supplies. Hospitals and other healthcare providers have been hit hard by the pandemic and supply chain leaders must continuously evaluate their strategic and tactical positions to address critical supply needs within their organizations. Longer-term and possibly substantive changes to the function and performance of healthcare supply chains will be necessary across multiple areas to meet demand more effectively during a crisis such as the COVID-19 global pandemic (Francis, 2020).

The implications of the pandemic have negatively impacted the health sector along with sectors such as economic, financial, labor, logistic and others (Mansour \& Al-Ajmi, 2020). Global business supply chains have experienced interruption due to restrictions placed on commercial transportation and therefore at times, the supply of goods and services has moved to minimal levels (Mansour \& Al-Ajmi, 2020). The negative impacts discussed here also impact small and major retailers alike, including those in the consumer defensive sector, specifically the discount store industry. At the start of the COVID-19 global pandemic, many big names in retailing bolstered company cash positions by leveraging their balance sheets, closing stores, lowering expenses, and suspending share-buyback programs as their top priorities to ensure financial flexibility (Young, 2020).

\subsection{Research in the Discount Store Industry Post COVID-19}

It is fair to say the COVID-19 global pandemic has negatively impacted retail supply chains (Berman, 2020). During this time retail managers have resorted to manual orders to assist in increasing on-hand inventory for items selling faster than standard replenishment systems could replenish the store's supply. In retailing, increasing supply can be more of a challenge compared to decreasing supply. The supply chain must be able to keep up with the increased demand for goods if this occurs over a longer period of time such as with the current pandemic. An example of this would be the increased demand for frozen foods while a shelter in place order was in effect in various parts of the world. The demand for frozen foods creates a problem at store level because stores cannot meet demand due to lack of refrigerated storage for the goods (Berman, 2020). Limited empirical research exists on the role of SCM in both the consumer defensive sector and the discount stores industry. This paper presents a unique opportunity to fill a void in the financial theory and SCM research for both the consumer defensive sector and the discount stores industry.

The organizations included in the study are based in the United States of America to allow for ample access to financial data and to avoid disparities in financial reporting. The companies studied include Walmart, Inc. (Walmart), Costco Wholesale Corporation (Costco), Target Brands, Inc. (Target), Dollar General Corporation (Dollar General), and Dollar Tree, Inc. (Dollar Tree). The companies selected for the study represent the top five organizations in terms of market capitalization. In addition, these firms represent both the sector and industry based on their overall footprint and financial performance over the past 10 years.

Big Lots, Tuesday Morning, and Ollie's were not included in this study due to their differences in structure and supply chain operations. For example, the Big Lots Of supply chain differs from that of Costco and others included 
in the study, as Big Lots does not purchase the bulk of their goods direct from the manufacturers. Rather, Big Lots is a bulk, liquidation type of retailer and a large percentage of their inventory is purchased from other retailers looking to move surplus products from their inventories or from retailers going out of business. Likewise, the same is true for Tuesday Morning, which according to founder Lloyd Ross, began as the world's greatest garage sale. Ollie's purchases much of its goods direct from manufacturers. However, the bulk of the merchandise is manufacturer surplus inventory or merchandise with dated packaging no longer being sold to more mainstream retailers. Therefore, Big Lots, Tuesday Morning, and Ollie's were not included in this study due to their differences in cost of goods, store structure, and supply chain operations.

\subsection{Theories and Models of Supply Chain Management}

Researchers in supply chain management (SCM) have long advocated for the application of existing organizational theories to supply chain problems. However, no supply chain theories have evolved in the 30 plus years since the discipline's inception. The most commonly used organizational theories in supply chain are Transaction Cost Economics, Agency theory, Resource-Based View, Resource-Dependence Theory, Network Theory, and Relational Exchange Theory. One of the contributions of this investigation is to apply financial theory to the supply chain problem.

Supply chain has several definitions with different implications depending on the users' point of view. Since the creation of SCM, five schools of thought have evolved: (1) supply chain awareness [Houlihan (1987), Jones and Riley (1985), Novack and Simco (1991), Oliver and Webber (1982)]; (2) linkage/logistics [Scott and Westbrook (1991), Turner (1993)]; (3) information [Towill, Naim and Wikner (1992)]; (4) process integrations [Cooper and Ellram (1993), Ellram and Cooper (1990)]; and (5) seamless supply chain [Childerhouse (2002), Stevens (1989)]. Supply chain awareness refers to managing the process in which the product flows from the company to the end user. Linkage/logistics deals with the union between an organizations functional area whilst information is associated with the flow of data among supply chain members. Process integration refers to integrating business process with corporate functions. Finally, seamless supply chain identifies and eliminates any obstacles that will impede the operation of the supply chain.

Organizational theories have been able to explain many of the dynamics of SCM. However, the fragmented and diverse nature of SCM issues have led to the limited development of a theoretical foundation. Another limitation to a consensus in SCM theory, is the dichotomy between applied research findings and conceptual ideas (Böhme, 2009). These limitations have resulted in the development of various models to explain SCM behavior. Modeling has been used extensively as a framework to understand problems in those disciplines that lack consistent theory. Four model classes have been developed in SCM research. The model classes are: (1) strategic; (2) operational; (3) network and: (4) behavioral.
Strategic models consist of applying organizational functions (e.g. accounting, finance, manufacturing, etc.) to influence supply chain. Operational models try to define the context, limits, and structure of SCM. Network models focus on explaining the implications of supply chain structure on business operations. Network modeling is the model class in which most empirical research has been conducted. Behavioral models examine the inter-organizational dynamics related to SCM and dominate the conceptual literature. The theories and models from other disciplines used in SCM research have been able to shed light on the complexities of supply chains and their implications in management actions. Yet, the lack of an overarching theory in SCM suggests further research in the discipline is needed to understand the role of supply chains in business operations.

The aim of this investigation is to develop a new model that measures supply chain efficiency. Financial ratios have long been an acceptable measure of business performance. Combining financial ratio methodology with SCM concepts gives rise to the Supply Chain Efficiency ratio.

\subsection{The Supply Chain Efficiency Ratio}

The Supply Chain Efficiency Ratio is an extension of the Efficiency Model from physics. The Efficiency Model states:

$$
\eta=W_{\text {out }} / E_{\text {in }}
$$

Where;

$\eta$ : efficiency

$W_{\text {out }}$ : The work or energy produced by a process.

$E_{i n}$ : The work or energy put into a process.

The seminal article "Defining Supply Chain Management" from Mentzer et al. (2001), interpreted Supply Chain Management as being comprised of the following eight issues: Planning, information, source, location, inventory, production, transportation, and the return of goods. In order to increase the attractiveness of the Supply Chain Efficiency Ratio, it needs to be easy to calculate, easy to understand, and consist of widely available data. The data would therefore need to be available in the financial statements of any public company. We need to assign values in the financial statements to the eight issues that make up Supply Chain Management.

Planning is associated with issues of realized product demand, costing, profit, and labor, which can be represented with the Gross Margin Ratio and the Debt Ratio. The information variable is related to issues of market perception, which can be measured by the Price-Earnings Ratio. Source and location are related to supplier logistics and accessibility, respectively. These variables can be measured by the Cost of Goods Sold or Cost of Sales. The Inventory Turnover Ratio measures the variables of inventory and production whilst the Days' Sales in Inventory Ration accounts for the transportation variable. Finally, the return of goods variable, which represents issues related to estimated warranty liabilities and sales refund payables are grouped in the current liabilities figure.

The Supply Chain Efficiency Ratio combines these variables into the following function: 
$f=$ (Gross Margin Ratio, Debt Ratio, P/E Ratio, Inventory

Turnover Ratio, Days Sales in Inventory Ratio, Current Liabilities)

Overlap exists in some of the formulas that represent the eight variables that make up Supply Chain Management. For instance, Cost of Goods Sold is represented in the Gross Margin Ratio. As such, the planning, source, and location variables are all represented. The Days' Sales Inventory Ratio is calculated using the Inventory Turnover Ratio. Therefore, the inventory, production, and transportation variables are grouped into Days' Sales Inventory. Finally, the Debt Ratio is calculated with total liabilities, which in turn includes the current liabilities consisting of labor, among others. So, the planning and return of goods variables are contained within the Debt Ratio.

As a result, we rearrange the function to the below to avoid multicollinearity:

\section{$f=$ (Gross Margin Ratio, Debt Ratio, P/E Ratio, Days' Sales in Inventory Ratio)}

Using the Efficiency formula as guide, we interpret which variables represent $W_{\text {out }}$ (i.e., the work produced by the process) and $E_{\text {in }}$ (i.e., the work put into the process). $W_{\text {out }}$ represents the results of operations whilst $E_{\text {in }}$ represent the resources needed to undertake the operations. The Gross Margin and P/E Ratios measure the profitability and market value of the organization, respectively. The Debt Ratio represents solvency and the Days' Sales in Inventory Ratio represents efficiency.

The Supply Chain Ratio can be written in the following manner:

\section{SCE $=($ Gross Margin Ratio * P/E Ratio) / (Debt Ratio * Days' Sales in Inventory Ratio)}

Where;

Gross Margin Ratio: (Revenue - Cost of Goods Sold) / Revenue

P/E Ratio: Stock Price / Earnings per Share

Debt Ratio: Total Liabilities / Total Assets

Days' Sales in Inventory: 365 / Inventory Turnover Ratio

Figure 1 presents the conceptual map of the ratio, which includes the variables that make up the model, their relationship, and the estimate that the model generates.

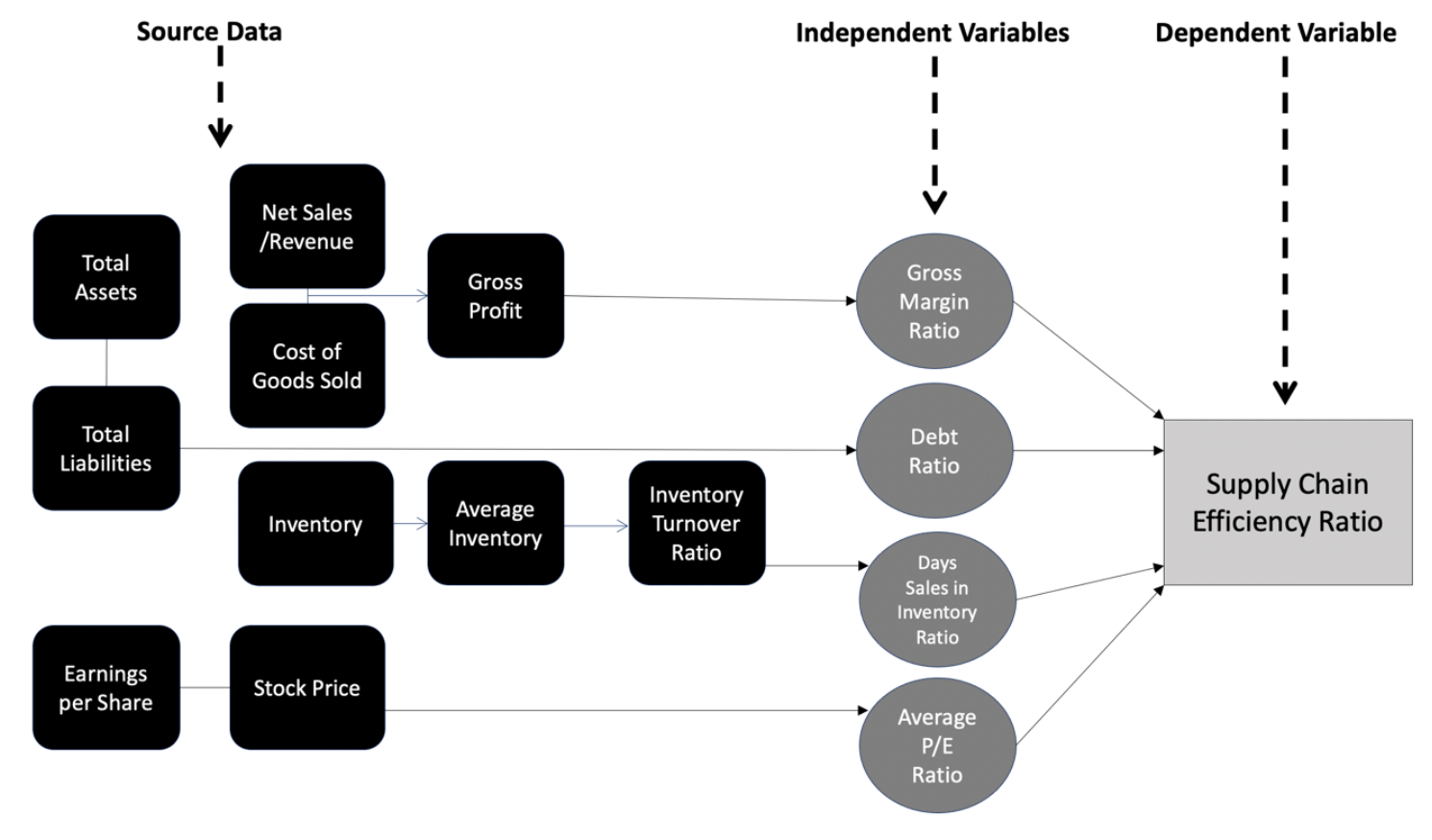

Figure 1 The conceptual map of the supply chain efficiency ratio

The Supply Chain ratio is interpreted in the same manner as the efficiency formula, which is the higher the result the more efficient the process. In the case of the ratio, a high figure indicates supply chain inefficiencies are not a concern whilst a low ratio indicates there may be issues in the supply chain that are negatively impacting organizational efficiency and/or corporate profits.

\section{RESEACH QUESTIONS}

RQ1: What is the relationship between supply chain performance (as measured by the Gross Margin Ratio, Debt Ratio, P/E Ratio, Inventory Turnover Ratio, Days Sales in Inventory Ratio, and the SCE ratio) and the SCE ratio?

\subsection{Research Hypothesis}

Null Hypothesis $\left(\mathrm{H}_{\mathrm{o}}\right)$ : There is no statistically significant relationship between Gross Margin Ratio, Debt Ratio, P/E Ratio, Inventory Turnover Ratio, Days Sales in Inventory Ratio, and the SCE ratio.

\section{METHOD}

The research objective of this study is to determine supply chain efficiency in the discount store industry based on changes to profit, debt, earnings, and inventory. The Supply Chain Efficiency ratio is used to conduct our analysis because it combines several independent variables that collect supply chain information. The variables in the model allow the researcher to assess the supply chain performance 
based on financial data. The indicators for the ratio are gross margin ratio, $\mathrm{P} / \mathrm{E}$ ratio, debt ratio, and days' sales in inventory. Data analysis includes testing the ability of the independent variables to determine the supply chain efficiency.

The SCE ratio generates a "score"; which is then placed in a comparative table for the researcher to assess the significance of said score. An average SCE Ratio for the Discount Store Industry will be calculated and used as the comparative unit of analysis. The Industry SCE Ratio will be determined by averaging the SCE Ratio of the eight existing U.S.-based public discount stores in the United States for the period 2000-2020, creating a composite score. The score is placed within a context of categories to interpret its analytic significance. The companies used for the SCE Ratio industry average are Walmart, Costco, Target, Dollar General, and Dollar Tree. Multiple regression analysis was used to examine some of the research hypotheses in this investigation because the objective was to determine an efficiency score from various predictors (Field, 2015).

\subsection{Research Instrument}

The research instruments in this study consist of data from the annual reports of each selected organization, MS Excel ${ }^{\circledR} 2010$, the regressions model, and the SCE ratio with the collected data at the .05 level of significance. The regression model was modified to reflect the time intervals to be observed. A regression analysis was conducted using Microsoft Excel 2010 with the data from the four groups of financial indicators, drawn from the annual reports of the examined organizations. The intent was to measure the predictability of the independent variables at different stages. Because the data in this study was drawn from existing sources of publicly held organizations, certain inherent biases from the originating source may have minimally affected the findings. The results could have been subject to participant biases or errors committed by the individual who published the data. The study assumed the collectors and handlers of the published data are objective. Neutrality was maintained in the study when collecting, coding, and analyzing the data.

\section{DATA}

The first hypothesis to be examined is whether there is a statistically significant relationship between Gross Margin Ratio, Debt Ratio, P/E Ratio, Inventory Turnover Ratio, Days Sales in Inventory Ratio, and SCE ratio. The process used to test this hypothesis, and all of the other hypotheses are a multiple regression model in the form of the SCE Ratio. Furthermore, we examined those indicators in the regression model that either proved or disproved the hypotheses. We found that the model showed the SCE Ratio is an indicator of supply chain efficiency in discount stores. After applying the SCE Ratio to test the hypothesis, we found that the $p$ value is less than .0005 and all results are considered to be statistically significant (see Table 1). Consequently, we reject the first null hypothesis.

\subsection{Regression Results for the Investigation's Hypotheses}

Table 1 The results of the regression model for the SCE ratio

\begin{tabular}{|c|c|c|c|c|c|c|c|}
\hline & & & & & & & Hypothesis Results \\
\hline & & Coefficients & t Stat & P-value & F-value & R Square & $\mathrm{H} 1$ \\
\hline \multirow{4}{*}{ Walmart } & Gross Margin Ratio & 0.9706 & 3.24 & 0.005122316 & \multirow{4}{*}{396.66} & \multirow{4}{*}{0.99} & \multirow{4}{*}{$\begin{array}{l}\text { Null hypothesis is } \\
\text { rejected }\end{array}$} \\
\hline & Average P/E Ratio & 0.0085 & 30.80 & 1.13484E-15 & & & \\
\hline & Debt Ratio & -0.3280 & -3.45 & 0.003273774 & & & \\
\hline & Days Sales in Inventory Ratio & -0.0054 & -5.47 & $5.08981 \mathrm{E}-05$ & & & \\
\hline \multirow{4}{*}{ Costco } & Gross Margin Ratio & 1.8929 & 4.41 & 0.000504896 & \multirow{4}{*}{373.70} & \multirow{4}{*}{0.99} & \multirow{4}{*}{$\begin{array}{l}\text { Null hypothesis is } \\
\text { rejected }\end{array}$} \\
\hline & Average P/E Ratio & 0.0080 & 32.77 & $2.24824 \mathrm{E}-15$ & & & \\
\hline & Debt Ratio & -0.3661 & -18.31 & $1.12812 \mathrm{E}-11$ & & & \\
\hline & Days Sales in Inventory Ratio & -0.0080 & -7.33 & 2.48413E-06 & & & \\
\hline \multirow{4}{*}{ Target } & Gross Margin Ratio & 0.5834 & 3.96 & 0.001256244 & \multirow{4}{*}{639.72} & \multirow{4}{*}{0.99} & \multirow{4}{*}{$\begin{array}{l}\text { Null hypothesis is } \\
\text { rejected }\end{array}$} \\
\hline & Average P/E Ratio & 0.0077 & 42.38 & 4.94345E-17 & & & \\
\hline & Debt Ratio & -0.1609 & -11.88 & 4.95409E-09 & & & \\
\hline & Days Sales in Inventory Ratio & -0.0028 & -4.57 & 0.000371623 & & & \\
\hline \multirow{4}{*}{ Dollar General } & Gross Margin Ratio & -2.0289 & -5.06 & 0.000141691 & \multirow{4}{*}{7835.67} & \multirow{4}{*}{1.00} & \multirow{4}{*}{$\begin{array}{l}\text { Null hypothesis is } \\
\text { rejected }\end{array}$} \\
\hline & Average P/E Ratio & 0.0033 & 133.47 & $1.75358 \mathrm{E}-24$ & & & \\
\hline & Debt Ratio & 0.0886 & 1.37 & 5.64859E-05 & & & \\
\hline & Days Sales in Inventory Ratio & -0.0034 & -7.62 & 1.5637E-06 & & & \\
\hline \multirow{4}{*}{ Dollar Tree } & Gross Margin Ratio & 1.6574 & 2.27 & 0.038228777 & \multirow{4}{*}{49.69} & \multirow{4}{*}{0.93} & \multirow{4}{*}{$\begin{array}{l}\text { Null hypothesis is } \\
\text { rejected }\end{array}$} \\
\hline & Average P/E Ratio & 0.0070 & 10.50 & 2.60827E-08 & & & \\
\hline & Debt Ratio & 0.0415 & 0.31 & 7.61487E-05 & & & \\
\hline & Days Sales in Inventory Ratio & 0.0006 & 8.73 & $2.90838 \mathrm{E}-07$ & & & \\
\hline
\end{tabular}

\section{RESULTS}

\subsection{Interpretation of SCE Ratio Results}

Model results suggest that the SCE Ratio serves as an indicator of corporate supply chain activity. Correlations were found between SCE Ratio scores and supply chain deficiencies. For instance, Dollar Tree had an SCE Ratio in 2003 of -0.071 , and in their 2004 Annual Report the company noted that volatility in gasoline prices negatively impacted their supply chains even though they had positive financial results (Dollar Tree, 2004). The company also had supply chain difficulties in 2019, reflected in their SCE Ratio of -0.105 . Dollar Tree had adopted an aggressive growth strategy since 2015. Opening up hundreds of new stores across the nation each year, which expanded their supply chain (Dollar Tree, 2019a). This expansion leveled off in 2019 due to a goodwill impairment charge that was not tax deductible in the fourth quarter of 2018 (Dollar Tree, 2019b). Resulting in a general expense increase of $\$ 2.86$ billion from the previous year, limiting their cash to continue the aggressive expansion. 
In another example, Dollar General had a -03.66 SCE Ratio in 2008, which caused the Industry SCE Ratio to move into negative values. In 2007, Dollar General had a merger with Buck Holdings, L.P. that resulted in increased debt and uncertainty in operations (Dollar General, 2008). The negative industry ratio may be a result of the small number of public companies (i.e., eight) that make up the industry, which makes each company's data congruous thus skewing the final results.

In 2014, Target had a data breach in their information and security systems, which directly impacted their supply chain (Target, 2014). The company's SCE Ratio for the year reflects this supply chain deficiency with a -0.186 score. The figures also show that Walmart and Costco, who have long been heralded as leaders in supply chain management, have maintained a steady SCE ratio throughout the observed time periods; consistently maintaining average SCE Ratios at or above the industry average.

\subsection{Assessment of Supply Chains in the Discount Store Industry during COVID-19}

Comparing the Discount Stores Industry average SCE Ratios, one can see the overall supply chain efficiency is down from 2019 into 2020 from 0.128 to 0.123 (see Table 2). This average drop in supply chain efficiency is due to the supply chain inefficiencies of Walmart and Dollar General respectively. In terms of the COVID-19 pandemic, it appears all of the companies studied performed well overall in 2020 with Dollar Tree and Target performing the best. This is based on their individual SCE ratios for 2020. This is most likely due to their overall financial strength and buying ability prior to the pandemic taking hold all around the globe.

Table 2 The SCE ratios for the top 5 U.S.-based discount stores

\begin{tabular}{|c|c|c|c|c|c|c|}
\hline Year & Walmart SCE Ratio & Costco SCE Ratio & Target SCE Ratio & $\begin{array}{c}\text { Dollar General SCE } \\
\text { Ratio }\end{array}$ & Dollar Tree SCE Ratio & Industry SCE Ratio \\
\hline 2020 & 0.206 & 0.064 & 0.134 & 0.107 & 0.142 & 0.123 \\
\hline 2019 & 0.421 & 0.202 & 0.097 & 0.135 & -0.105 & 0.128 \\
\hline 2018 & 0.264 & 0.181 & 0.099 & 0.140 & 0.099 & 0.161 \\
\hline 2017 & 0.167 & 0.171 & 0.074 & 0.131 & 0.138 & 0.132 \\
\hline 2016 & 0.138 & 0.193 & 0.105 & 0.158 & 0.414 & 0.244 \\
\hline 2015 & 0.131 & 0.168 & 0.106 & 0.175 & 0.268 & 0.190 \\
\hline 2014 & 0.137 & 0.173 & -0.186 & 0.156 & 0.174 & 0.016 \\
\hline 2013 & 0.134 & 0.158 & 0.171 & 0.155 & 0.242 & 0.130 \\
\hline 2012 & 0.137 & 0.187 & 0.108 & 0.193 & 0.271 & 0.187 \\
\hline 2011 & 0.129 & 0.193 & 0.103 & 0.154 & 0.136 & 0.139 \\
\hline 2010 & 0.148 & 0.163 & 0.118 & 0.206 & 0.118 & 0.149 \\
\hline 2009 & 0.143 & 0.156 & 0.105 & 0.437 & 0.100 & 0.491 \\
\hline 2008 & 0.154 & 0.245 & 0.150 & -3.660 & 0.051 & -0.413 \\
\hline 2007 & 0.140 & 0.179 & 0.098 & 0.291 & 0.073 & 0.151 \\
\hline 2006 & 0.139 & 0.196 & 0.179 & 0.131 & 0.059 & 0.142 \\
\hline 2005 & 0.169 & 0.184 & 0.211 & 0.171 & 0.051 & 0.240 \\
\hline 2004 & 0.220 & 0.181 & 0.192 & 0.194 & 0.069 & 0.227 \\
\hline 2003 & 0.245 & 0.168 & 0.155 & 0.093 & -0.071 & 0.133 \\
\hline 2002 & 0.290 & 0.190 & 0.189 & 0.101 & 0.144 & 0.037 \\
\hline 2001 & 0.264 & 0.227 & 0.213 & 0.395 & 0.123 & 0.178 \\
\hline 2000 & 0.290 & 0.311 & 0.175 & 0.142 & 0.163 & 0.167 \\
\hline Average & 0.194 & 0.191 & 0.124 & 0.000 & 0.127 & 0.142 \\
\hline
\end{tabular}

Walmart experienced the largest shift in its supply chain efficiency ratio from 2019 to 2020. The impact Walmart experienced is partly due to its 10,000 plus stores it operates and must supply with products globally. In addition, COVID-19 originated in China and had huge implications for manufacturers and suppliers in this area of the world and likewise, the retailers supplied. Given that Walmart imports approximately 70 percent of its goods from China (Chan, 2011), the initial COVID-19 outbreak in China had a significant impact on Walmart's supply chain and available inventory.

Walmart has also experienced an increase in costs by supplying PPE supplies for associates in their distribution centers and all store locations. Dollar General is in a similar situation in terms of their supply chain disruption due to COVID-19. The company has experienced shortages, similar to other discount store chains, for paper goods and other related products, along with the increased costs for PPE supplies for warehouse employees. Costco had a similar shift going from an SCE Ratio of .202 in 2019, well above the industry average, to a .064 ratio for 2020. Costco had similar difficulties as Walmart during COVID-19 since they have comparable supply chains. Costco's supply chain is also dependent on Chinese trade and the U.S.-China Trade war, along with the health crisis, had an impact on their performance.

The overall positive performance of the companies during the pandemic speaks to the strength of their supply chains and the number of days of inventory on-hand in both physical stores and distribution centers. Barring another major supply chain disruptor, it appears all of the discount stores in the study should be able to perform in a similar manner through the end of 2020 and into 2021. Retail managers can utilize the SCE Ratio to identify and address potential supply chain efficiency issues before the problem strikes a major blow to the retailer's operations and financial outlook and therefore, potentially saving the retailer millions of dollars in revenue and profit. 


\section{CONCLUSION}

In conclusion, correlations were found between SCE Ratio scores and supply chain deficiencies. The findings of this research provide mathematical proof of supply chain impacts and deficiencies experienced by the discount store retailers studied. The deficiencies can be traced and correlated to both discount store news concerning retailer operations and published financial results. In addition, the application of the SCE Ratio provides proof of an efficient supply chain. Likewise, the application of the SCE Ratio also provides proof on an inefficient supply chain. The results of this study showed that during the first year of the COVID-19 pandemic, Dollar Tree and Target outperformed other discount store retailers in the space. This conclusion is based on their individual SCE ratios for 2020. Therefore, it can also be concluded the Dollar Tree and Target supply chains, in terms of their efficiency, operated in a superior manner, in the consumer defensive sector and the discount store industry, for the timeline studied.

Additional research is still needed in the areas of supply chain efficiency and its influence on firm financial performance. This investigation is the first contribution of the impact of supply chain efficiency on firm performance within the discount store industry. A significant motivation of the authors was to begin empirical research on the influence of COVID-19 on supply chain and firm finances. Further research is warranted on the impact of the COVID19 pandemic on supply chains within other sectors, more specifically the Consumer Discretionary and Energy sectors.

\section{REFERENCES}

Berman, J. (2020, 07). New study looks at impact of covid-19 on retail supply chains. Modern Materials Handling, 75, 9-11.

Böhme, T. (2009). Supply chain integration: A case-based investigation of status, barriers, and paths to enhancement (Doctoral thesis, University of Waikato, Hamilton, New Zealand). Retrieved from http://researchcommons.waikato.ac.nz/handle/10289/3289

Chan, A. (2011). Walmart in China. Cornell University Press. ProQuest Ebook Central, https://ebookcentral.proquest.com/lib/apus/detail.action?doc ID $=3138262$.

Childerhouse, P. (2002). Enabling seamless market-orientated supply chains (Doctoral thesis, Cardiff University, Wales, UK). Retrieved from http://ethos.bl.uk/OrderDetails.do?uin=uk.bl.ethos. 273642

Cooper, M. C., \& Ellram, L. M. (1993). Characteristics of supply chain management and the implications for purchasing and logistics strategy. The International Journal of Logistics Management, 4(2), 13-24.

Dollar General. (2008, June 30). Annual report. https://investor.dollargeneral.com/download/companies/doll argeneral/Annual\%20Reports/2008 10-K.pdf

Dollar Tree. (2004, June 16). Annual report. https://www.dollartreeinfo.com/static-files/8a1d14e3-2f1143eb-b916-49e3643c855a

Dollar Tree. (2019a, April 9). Annual report. https://www.dollartreeinfo.com/static-files/a85ce139-7dde449f-88ff-c0cf1f2e6716

Dollar Tree. (2019b, March 6). Q4-18 earnings press release with tables.

https://www.sec.gov/Archives/edgar/data/935703/00009357 0319000016/ex991q4-18earningspressrel.htm

Eckstein, D., Goellner, M., Blome, C., \& Henke, M. (2015). The performance impact of supply chain agility and supply chain adaptability: the moderating effect of product complexity International Journal of Production Research, 53(10), 30283046.

Elert, G. (2020, January). Efficiency. The physics hypertextbook. https://physics.info/equations/

Ellram, L. M., \& Cooper, M. C. (1990). Supply chain management, partnership, and the shipper-third party relationship. The International Journal of Logistics Management, 1(2), 1-10.

Field, A. P. (2015). Discovering Statistics using SPSS. London, United Kingdom: Sage Publications.

Francis, J. R., F.A.C.H.E. (2020). COVID-19: Implications for supply chain management. Frontiers of Health Services Management, 37(1),

33-38. doi:http://dx.doi.org.ezproxy1.apus.edu/10.1097/HAP.00000 00000000092

Gligor, D. (2017). Re-Examining Supply Chain Fit: An Assessment of Moderating Factors. Journal of Business Logistics, 38(4), 253-265.

Houlihan, J. B. (1987). International supply chain management. International Journal of Physical Distribution \& Logistics Management, 17(2), 51-66.

Jones, T. C., \& Riley, D. W. (1985). Using inventory for competitive advantage through supply chain management. International Journal of Physical Distribution \& Logistics Management, 15(5), 16-26.

Khan, H. \& Wisner, J.D. (2019). Supply Chain Integration, Learning, and Agility: Effects on Performance. Operations and Supply Chain Management, 12(1), 14-23.

Lau, K. H. (2012). Demand management in downstream wholesale and retail distribution: A case study. Supply Chain Management, 17(6), 638-654 doi:http://dx.doi.org.ezproxy1.apus.edu/10.1108/135985412 11269247.

Liao, S. \& Widowati, R. (2021). A supply chain management study: A review of theoretical models from 2014 to 2019 Operations and Supply Chain Management, 14(2), 173 - 188.

Mansour, J., \& Al-Ajmi, S. (2020). Coronavirus 'COVID-19' Supply chain disruption and implications for strategy, economy, and management. The Journal of Asian Finance, Economics and Business. 7(9,) 659-672. doi:https://doi.org/10.13106/jafeb.2020.vol7.no9.659

Mentzer, J., Dewitt, W., Keebler, J., Min, S., Nix, N., Smith, C., \& Zacharia, Z. (2001). Defining supply chain management. Journal of Business Logistics. 22. 10.1002/j.21581592.2001.tb00001.x.

Mukhtar, U. \& Azhar, T.H. (2020). Inter-functional Coordination to Co-create Value Within Integrated Value Chains for Competitive Supply Chain, Operations and Supply Chain Management 13(1), $11-22$

Novack, R. A., \& Simco S. W. (1991). The industrial procurement process: A supply chain perspective. Journal of Business Logistics, 12(1), 145-167.

Oliver, R. K., \& Webber, M. D. (1982). Supply-chain management: Logistics catches up with strategy. In M. Christopher (Ed.), Logistics: The strategic issue (pp. 63-75): London, UK: Chapman \& Hall.

Scott, C., \& Westbrook, R. (1991). New strategic tools for supply chain management. International Journal of Physical Distribution \& Logistics Management, 21(1), 23-33.

Stevens, G. C. (1989). Integrating the supply chain. International Journal of Physical Distribution \& Logistics Management, 19(8), 3-8.

Singh, J., \& Raghuvanshi, R. (2014). Role of supply chain management in retail sector. International Journal of Management Research and Reviews, 4(11), 1091-1103.

Target. (2014, April 27). Annual report. https://investors.target.com/static-files/25786cd8-19a2$\underline{4895-938 \mathrm{~d}-519 \mathrm{c} 02157000}$ 
Towill, D. R., Naim, M. M., \& Wikner, J. (1992). Industrial dynamics simulation models in the design of supply chains. International Journal of Physical Distribution \& Logistics Management, 22(5), 3-13.

Turner, J. R. (1993). Integrated supply chain management: What's wrong with this picture? Industrial Engineering, 25(12), 5255 .

Walters, D. (2006). Demand chain effectiveness - supply chain efficiencies: A role for enterprise information management. Journal of Enterprise Information Management, 19(3), 246. doi:http://dx.doi.org.ezproxy2.apus.edu/10.1108/174103906 10658441.

Wiengarten, F., Pagell, M., Ahmed, M. U., \& Gimenez, C. (2014). Do a country's logistical capabilities moderate the external integration performance relationship? Journal of Operations Management, 32(1-2), 51-63

Wong, C. W., Lai, K. H., \& Bernroider, E. W. (2015). The performance of contingencies of supply chain information integration: The roles of product and market complexity. International Journal of Production Economics, 165, 1-11.

Yalcin, H., Shi, W., \& Rahman, Z. (2020). A review and scientometric analysis of Supply Chain Management (SCM). Operations and Supply Chain Management, 13(2), 123-133.

Yoon, S. N., Lee, D., \& Schniederjans, M. (2016). Effects of innovation leadership and supply chain innovation on supply chain efficiency: Focusing on hospital size. Technological Forecasting and Social Change, 113, 412-421.

Young, V. M. (2020). Retail's COVID-19 strategy? Hoard cash to ride out virus storm. Sourcing Journal (Online).

Dr. Kevin Forehand is an Associate Professor in the Dr. Wallace E. Boston School of Business at American Public University System. Dr. Forehand's industry background is primarily in Retail Management and Sales Management, having managed and operated stores for over 20 years. Dr. Forehand has held many different positions during his time in retail and sales from Sales Associate to Support Manager, Assistant Store Manager, General Manager, Store Manager, District Manager, and Vice President of Store Operations. Dr. Forehand's research interests include supply chain management and retail management.

Dr. Juan Román has over ten years of experience in the private sector working in the accounting and finance industry, seven years of experience as an accounting and finance professor in various universities across the United States, and five years of public service as an Operations Officer for the Central Intelligence Agency. Dr. Román's research interests include supply chain management, logistics, accounting, and finance-related topics.

Dr. Thomas Schaefer is an Associate Professor at American Public University System, Dr. Wallace E. Boston School of Business. Dr. Schaefer has served in a variety of senior management positions within Fortune 500 companies. Dr. Schaefer provides guidance and services to large and medium sized organizations who are seeking to enhance and refine organizational effectiveness, business process, and overall profitability. Dr. Schaefer's research interests include supply chain management, operations management, and strategic management. 